\title{
Meiotic Chromosome Numbers in 9 Iranian Species of Oryzopsis (Poaceae)
}

\author{
Masoud Sheidai ${ }^{1, *}$, Zahra Yazdanbakhsh ${ }^{2}$ and Zahra Noormohammadi ${ }^{2}$ \\ ${ }^{1}$ Shahid Beheshti University, GC, Faculty of Biological Sciences, Tehran, Iran \\ ${ }^{2}$ Biology Department, School of Basic sciences, Science and Research Branch, \\ Islamic Azad University (SRBIAU), Poonak, Tehran, Iran
}

Received January 1, 2010; accepted February 1, 2010

\begin{abstract}
Summary Meiotic studies were performed in 9 Oryzopsis species of $O$. pubiflora, O. lateralis, $O$. holciformis, $O$. barbellata, $O$. munroi, O. microcarpa, $O$. sphacelata, $O$. virescense and $O$. molinioides showing the presence of $2 n=2 x=24$ in all nine species studied. The species studied were diploid and had 12 chromosome number, and in O. microcarpa, O. sphacelata, O. molinioides and $O$. virescense chromosomes are new count. B-chromosomes 0-2 were observed in all species studied, which were smaller than A-chromosomes and did not pair with them. T-test analysis between the cells with B-chromosomes and those devoid of Bs showed significant difference in chiasma frequency and distribution as well as in chromosomes pairing only in O. munroi, with significant reduction in meiotic values in the presence of B-chromosomes. The occurrence of large pollen grains (possibly unreduced pollen grains) was observed along with small (normal) pollen grains in these species. Significant difference observed in chiasma frequency and distribution among species studied may be of use in species delimitation. Moreover species relationships obtained based on cytological data partly supports taxonomic treatment of the genus.
\end{abstract}

Key words B-chromosome, Chiasma frequency, Meiotic chromosome number, Oryzopsis.

Rice grass (Oryzopsis Michx.) is a genus with about 35 open habitats species which are hermaphroditic, caespitose, tufted perennials, growing in temperate and subtropical regions of northern hemisphere and Middle East, occupying mainly dry mountain slopes. However, a few species occur in woodland (Watson and Dallwitz 1992). Oryzopsis species show close affinity and frequently hybridize with the Stipa species (Johnson 1945a, 1945b, 1960, 1962, 1963, Hitchcock and Spellenberg 1968, Shechter 1969, Spellenberg and Mehlenbacher 1971). About 10 species are reported from Iran (Bor 1970). The chromosome base numbers of the genus Oryzopsis are $x=11$, 12, and 14. Diploid, tetraploid, pentaploid and even higher ploidy levels have been reported in this genus (Watson and Dallwitz 1992).

Cytotaxonomical studies have been considered useful in showing species relationships, taxonomic delimitation and genetic differences in several plant groups including grass genera of Aegilops (Sheidai et al. 1999, 2000, 2002), Bromus (Stebbins 1981, Sheidai and Nouroozi 2005, Sheidai and Fadaei 2005, Sheidaei et al. 2008), Stipa (Stebbins 1998, Sheidai and Attaei 2005, Sheidai et al. 2006), Festuca (Sheidai and Bagheri-Shabestarei 2007a), and Hordeum (Sheidai and Rashid 2007), as well as in other plant groups like Asparagus (Sheidai and Inamdar 1997), Hyoscyamus (Sheidai et al. 1999) and Echinops (Sheidai et al. 2000).

Cytological reports on Oryzopsis species are very limited (Johnson and Rogler 1943, Johnson 1945a, 1945b, 1960, 1962, 1963, Hitchcock and Spellenberg 1968, Shechter 1969, Spellenberg and Mehlenbacher 1971, Sharma and Sharma 1979, Love and Love 1981a) and there is only 1 report from Iran dealing with chromosome pairing in 4 species only (Yazdanbakhsh et al. 2010).

\footnotetext{
*Corresponding author, e-mail: msheidai@yahoo.com
} 
Table 1. Meiotic characteristics in Oryzopsis species

\begin{tabular}{|c|c|c|c|c|c|c|c|}
\hline Species & Locality & TX & IX & TOX & RII & $\mathrm{RD}$ & I \\
\hline O. monilioides & Fars, Bel montain & 20.70 & 2.50 & 23.20 & 9.85 & 1.20 & 1.90 \\
\hline O. munroi & Khorasane razavi, Kalate & 21.47 & 4.50 & 26.00 & 10.80 & 0.02 & 2.20 \\
\hline O. sphacelata & Fars, Bazbache & 17.00 & 6.00 & 23.10 & 8.30 & 0.37 & 6.58 \\
\hline O. lateralis & Fars, Bel mountain & 18.70 & 4.00 & 22.80 & 8.90 & 1.32 & 3.57 \\
\hline O. holciformis & Mazandaran, Rozan & 23.40 & 2.40 & 25.80 & 11.60 & 0.20 & 0.40 \\
\hline O. virescense & Mazandaran, Taker & 19.50 & 1.90 & 21.40 & 9.50 & 0.50 & 3.70 \\
\hline O. microcarpa & Khorasane razavi, Ghonchi & 23.50 & 2.00 & 25.40 & 11.70 & 0.10 & 0.40 \\
\hline O. pubiflora & Hanna lake Esfahan & 13.78 & 4.44 & 18.23 & 6.94 & 0.24 & 9.42 \\
\hline O. barbellata & Tehran, Touchal mountain & 22.30 & 7.30 & 29.70 & 11.30 & 0.17 & 0.33 \\
\hline
\end{tabular}

Abbreviations: $\mathrm{TX}=$ Mean number of terminal chiasmata, $\mathrm{IX}=$ Mean number of intercalary chiasmata, $\mathrm{TOX}=\mathrm{Mean}$ number of total chiasmata, $\mathrm{RB}=$ Mean number of ring bivalents, $\mathrm{RD}=$ Mean number of rod bivalents, $\mathrm{I}=$ Mean number of univalents.

Table 2. ANOVA test of meiotic characteristics in Oryzopsis species

\begin{tabular}{|c|c|c|c|c|c|c|}
\hline & & $\begin{array}{l}\text { Sum of } \\
\text { Squares }\end{array}$ & $\mathrm{df}$ & $\begin{array}{l}\text { Mean } \\
\text { Square }\end{array}$ & $\mathrm{F}$ & Sig. \\
\hline \multirow[t]{3}{*}{$\mathrm{TX}$} & Between Groups & 144.343 & 6 & 24.057 & 4.077 & .005 \\
\hline & Within Groups & 165.200 & 28 & 5.900 & & \\
\hline & Total & 309.543 & 34 & & & \\
\hline \multirow{3}{*}{ IX } & Between Groups & 72.571 & 6 & 12.095 & 4.980 & .001 \\
\hline & Within Groups & 68.000 & 28 & 2.429 & & \\
\hline & Total & 140.571 & 34 & & & \\
\hline \multirow[t]{3}{*}{ TOX } & Between Groups & 144.286 & 6 & 24.048 & 2.256 & .067 \\
\hline & Within Groups & 298.400 & 28 & 10.657 & & \\
\hline & Total & 442.686 & 34 & & & \\
\hline \multirow[t]{3}{*}{$\mathrm{RB}$} & Between Groups & 45.600 & 6 & 7.600 & 4.092 & .005 \\
\hline & Within Groups & 52.000 & 28 & 1.857 & & \\
\hline & Total & 97.600 & 34 & & & \\
\hline \multirow[t]{3}{*}{$\mathrm{RD}$} & Between Groups & 7.886 & 6 & 1.314 & 1.769 & .142 \\
\hline & Within Groups & 20.800 & 28 & .743 & & \\
\hline & Total & 28.686 & 34 & & & \\
\hline \multirow[t]{3}{*}{ I } & Between Groups & 135.771 & 6 & 22.629 & 3.845 & .006 \\
\hline & Within Groups & 164.800 & 28 & 5.886 & & \\
\hline & Total & 300.571 & 34 & & & \\
\hline
\end{tabular}

$\mathrm{TX}=$ Mean number of terminal chiasmata, $\mathrm{IX}=$ Mean number of intercalary chiasmata, $\mathrm{TOX}=$ Mean number of total chiasmata, $\mathrm{RB}=$ Mean number of ring bivalents, $\mathrm{RD}=$ Mean number of rod bivalents, $\mathrm{I}=$ Mean number of univalents.

Therefore the present study considers ploidy level, chromosome pairing and meiotic characteristics of 9 Oryzopsis species growing wild in Iran for the first time.

Materials and methods

\section{Plant material}

In our plant material collections, young flower buds could be obtained for 9 Oryzopsis species growing in Iran (Table 1), namely: O. pubiflora Hack., O. lateralis (Regel) Stapf., O. holciformis (M.B) Hack., O. barbellata (Mez) Bor., O. munroi Stapf, O. microcarpa Pilger, O. sphacelata (Boiss. and Buhse) Hack., O. virescense (Trin.) Beck. and O. molinioides (Boiss.) Hack. Ex Paulsen. The voucher specimens are deposited in the Herbarium of Shahid Beheshti University (HSBU). 


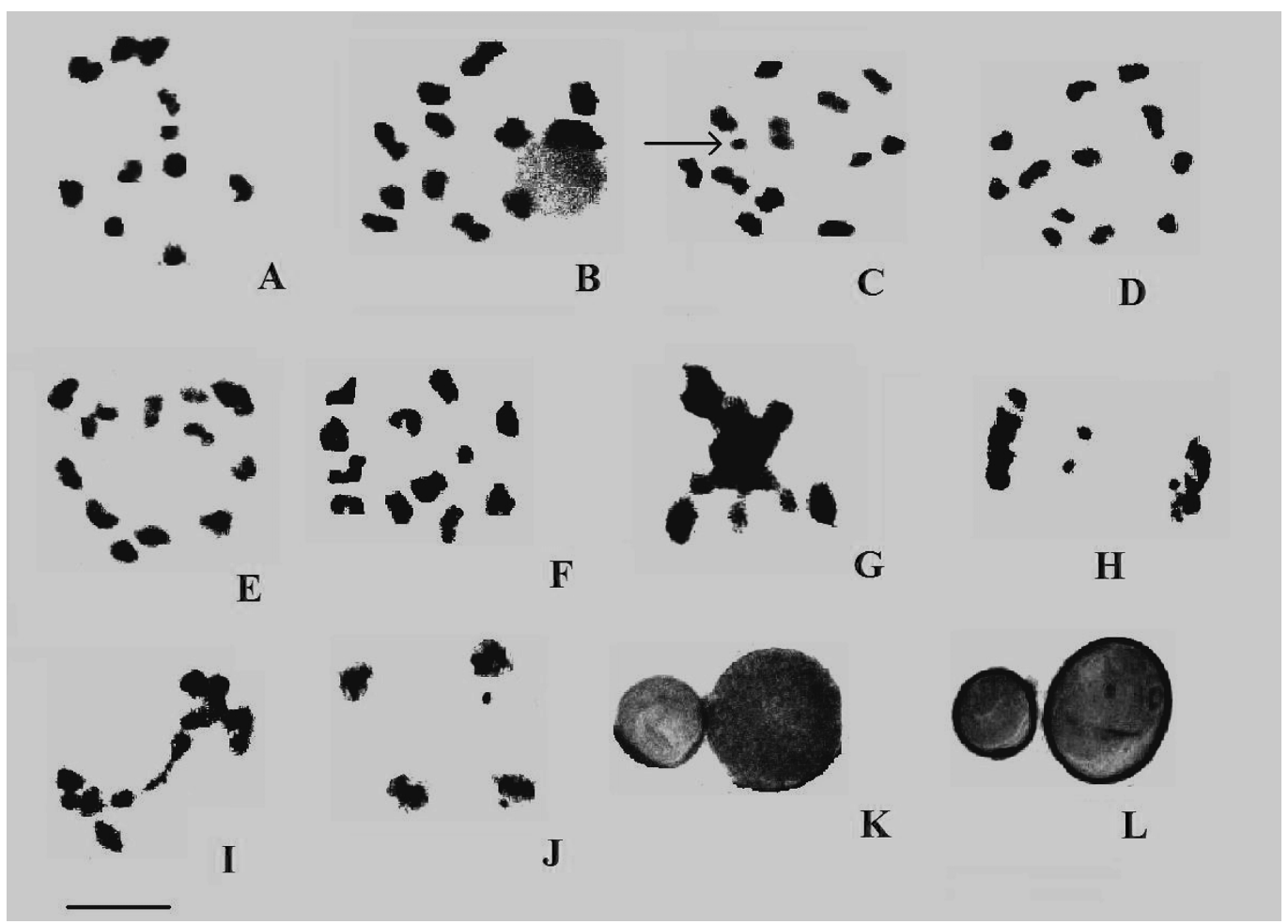

Fig. 1. Representative meiotic cells in Oryzopsis species. A: Metaphase I cell showing bivalents in $O$. microcarpa. B: Diakinesis cell showing bivalents in $O$. munroi. C: Metaphase I cell showing Bchromosome (arrow) in $O$. munroi. D-F: Metaphase I cells showing bivalents in $O$. holciformis, $O$. virescense and $O$. sphacelata respectively. G-I: Meiotic cells showing stickiness, laggard chromosomes, anaphase bridge and telophase II laggards in $O$. munroi respectively. $\mathrm{K}$ and L: Potential unreduced pollen grains (larger pollen grains) in $O$. munroi and $O$. monilioides respectively. Scale bar $=10 \mu \mathrm{m}$.

\section{Cytological studies}

Meiotic studies were performed on young flower buds collected from at least 10 randomly selected plants from each species and population. A minimum of 100 metaphase/diakinesis pollen mother cells (PMCs) and 500 anaphase and telophase cells were analysed for data collection (Sheidai and Rashid 2007). Pollen stainability as a measure of fertility was determined by staining minimum 1000 pollen grains with $2 \%$ acetocarmine: 50\% glycerin $(1: 1)$ for about $1 / 2 \mathrm{~h}$. Round complete pollens which were stained were taken as fertile, while incomplete, shrunken pollens with no stain were considered as infertile (Sheidai and Rashid 2007).

\section{Statistical analyses}

An analysis of variance (ANOVA), followed by a Least Significant Test (LSD), was performed to detect any significant difference in chiasma frequency and chromosome pairing among the species studied (Sheidai and Rashid 2007). A t-test analysis was performed to study size difference between normal and large pollen grains. At least 50 large pollen grains and 50 small pollen grains were randomly measured for t-test analysis. This t-test analysis was performed to detect any significant difference in chiasma frequency and chromosome pairing among the cells with and without B-chromosomes. Grouping of the species was done by using different clustering methods, including Unweighted Paired Group with Arithmetic Average (UPGMA) and Neighbor Joining 


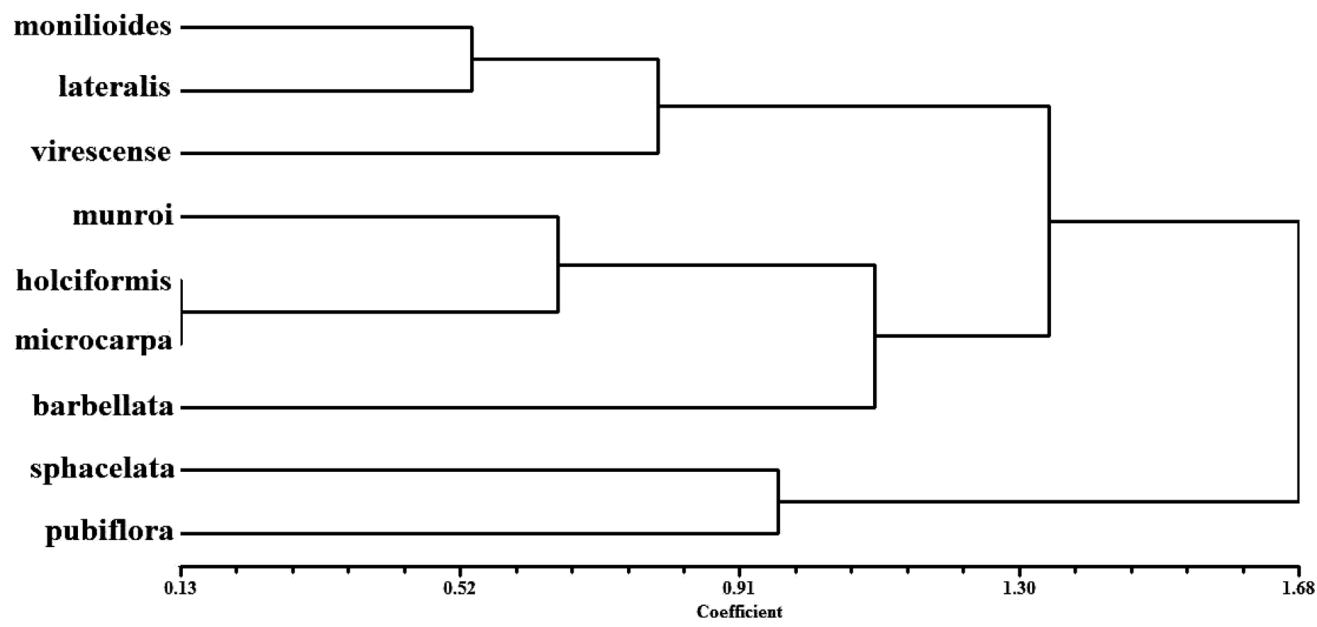

Fig. 2. UPGMA dendrogram of Oryzopsis species based on cytological data.

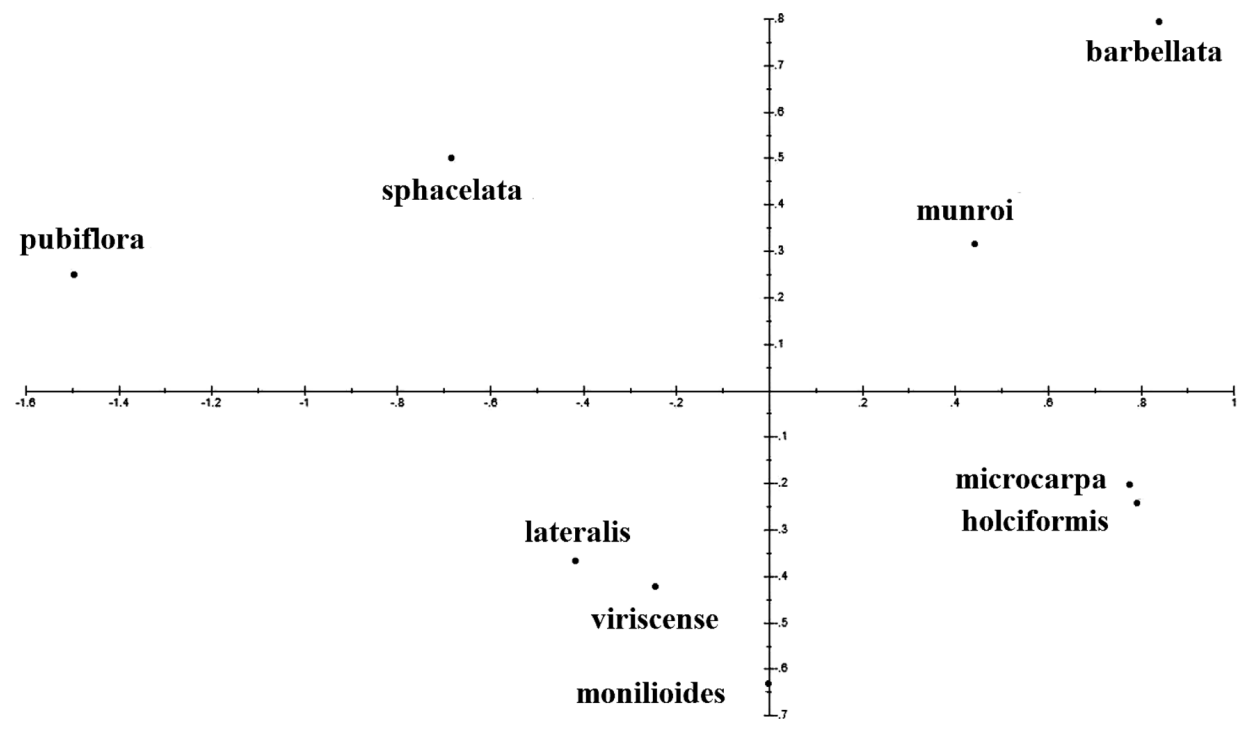

Fig. 3. PCA plot of Oryzopsis species based on cytological data.

(NJ) as well as ordination plot based on Principal Components Analysis (PCA) (Sheidai and Rashid 2007). Statistical analyses used SPSS ver. 9 (1998), NTSYS ver. 2.2 (1998) and DARwin ver. 5. (2000) software.

\section{Results}

\section{Chromosome number and chiasma frequency}

The species and populations studied were diploid and possessed $2 n=2 x=24$ chromosome number (Table 1, Fig. 2A-I), supporting the earlier reports on $O$. holciformis var holciformis, $O$. holciformis var. longiglumis, O. molinioides, O. barbellata, O. pubiflora, O. munroi and O. lateralis 
(Sharma and Sharma 1979, Nasirzadeh et al. 2004, Sheidai et al. 2010). To our knowledge the chromosome number of $O$. microcarpa, $O$. sphacelata, $O$. molinioides and $O$. virescense are new to science.

$O$. barbellata showed the highest value of intercalary and total chiasmata as well as ring bivalents (7.30, 29.70 and 11.30 respectively), while $O$. microcarpa had the highest value of terminal chiasmata (23.50). The lowest value of total chiasmta and ring bivalents occurred in $O$. pubiflora (18.23 and 6.94 respectively), while the lowest value of intercalary chiasmata occurred in $O$. virescense (1.90). Univalents were formed in all the species and populations studied with $O$. pubiflora showing the highest mean value (9.42) and $O$. barbellata showing the lowest value $(0.33)$.

Oryzopsis species studied showed a high percentage of pollen fertility (about 100\%). The ANOVA test (Table 2) showed a significant difference $(p<0.05)$ in chiasma frequency and distribution as well as chromosome association among Oryzopsis species studied.

Laggard chromosomes were observed in anaphase of meiosis-I in $O$. munroi, O. molinioides and $O$. lateralis (Fig. $1 \mathrm{H}$ ), ranging from $1.10-3.82 \%$. Such laggards may have formed micronuclei observed in these species (Fig. 1J). Metaphase and anaphase II stickiness occurred in $O$. microcarpa and $O$. holciformis (Fig. 1I).

Grouping of the Oryzopsis species, based on cytological data obtained by different clustering and ordination methods, produced similar results (Figs. 2, 3), showing similarities between $O$. molinioides, $O$. lateralis and $O$. virescense which is not supported by taxonomic treatment of the genus in Flora Iranica (Bor 1970), as these 3 species have been placed far from each other.

The second cluster or group identified shows close affinity among $O$. holciformis, $O$. microcarpa, O. munroi and $O$. barbellata, with higher similarity between the first 2 species. Such species affinities have been also suggested by Bor (1970) in his taxonomic treatment of the genus. Both cluster and ordination results suggest close relationship between $O$. sphacelata and $O$. pubiflora, which is also suggested in Flora Iranica.

\section{B-chromosomes}

B-chromosomes (Bs) of 0-2 were observed in all species studied (Fig. 1C), which were smaller than A-chromosomes and did not pair with them. Bs could arrange them in the equator and move to the poles being included in the telophase nucleus. This is the first report on the occurrence of Bs in O. microcarpa, O. sphacelata, O. molinioides and $O$. virescense.

The t-test analysis between the cells with Bs and those devoid of Bs showed significant differences in chiasma frequency and distribution as well as in chromosomes pairing only in $O$. munroi, with significant reduction in meiotic values in the presence of Bs.

\section{Large pollen grains}

The occurrence of large pollen grains (possibly $2 n$ pollen grains) was observed along with smaller (normal) pollen grains in O. munroi, O. monilioides and O. virescense (Fig. $1 \mathrm{~K}$ and L). $2 \%$ of the analysed pollen grains are large in these species. The size of small (reduced) pollen grains ranged from 27 to $31 \mu \mathrm{m}($ mean $=29 \mu \mathrm{m})$ in $O$. munroi, while the size of larger pollen grains (reduced) ranged from 35 to $45 \mu \mathrm{m}$ (mean $=40 \mu \mathrm{m})$. Similarly, the size of small (reduced) pollen grains ranged from 30 to $36 \mu \mathrm{m}$ (mean $=33 \mu \mathrm{m}$ ) in $O$. monilioides, while the size of larger pollen grains (reduced) ranged from 38 to $41 \mu \mathrm{m}$ (mean $=39.5 \mu \mathrm{m}$ ). In $O$. virescense, small pollen grains ranged from $32-38 \mu \mathrm{m}($ mean $=36 \mu \mathrm{m})$ and larger pollen grains ranged in size from 39 to $46 \mu \mathrm{m}$ (mean $=43 \mu \mathrm{m}$ ). A t-test analysis of the size of pollen grains showed that larger pollen grains differ significantly from the small pollen grains $(p<0.05)$ 


\section{Discussion}

Variations reported in the chromosome numbers of Oryzopsis species indicate the presence of 2 basic chromosome numbers of $x=11$ and $x=12$ in the genus and the possible role played by aneuploidy and chromosome loss/gain during the species diversification.

Significant differences observed in chiasma frequency and localization among Oryzopsis species studied may indicate partly their genetic difference (Quicke 1993) and possible significant change in the genes controlling chromosome pairing in the genus. Such variations have been reported in populations of different species (Rees and Jones 1977), and are considered as a means for generating new forms of recombination influencing the variability within natural populations in an adaptive way (Rees and Jones 1977). As stated before, different species of Oryzopsis can cross spontaneously, which could give rise to intermediate types adding to the species diversity and variability in the genus. The results of clustering and ordination plots showed that cytological data might be of use in Oryzopsis species delimitation and revealing the species relationships.

Bs are reported in more than 1300 species of plants and almost 500 species of animals (Camacho et al. 2000). The occurrence of Bs in all the species and populations studied may indicate the role played by these chromosomes in species diversification and adaptation. However, the present analyses only showed an significant effects on chiasma frequency and distribution in 1 species, but even slight non-significant changes may have some affects on the plants possessing them. Our previous studies on the effect of Bs on chiasma frequency and distribution as well as chromosome pairing in grass species have indicated a significant increase in Bromus and Aegilops species (Sheidaei et al. 1999, Sheidai and Nouroozi 2005).

The occurrence of significantly larger pollen grains in some of the Oryzopsis species may indicate the occurrence of potential unreduced pollen grains in these species, which has also been reported before for O. lateralis, O. pubiflora and O. barbellata (Yazdanbakhsh et al. 2010).

Unreduced gametes are known to produce individuals with a higher ploidy level through a process known as sexual polyploidization (Villeux 1985), which has been considered the major route to the formation of naturally occurring polyploids. Such polyploid plants may grow in the vicinity of diploid parental plants, but in our study the species and populations studied showed diploid chromosome number and polyploid plants/species were not identified by us. This may indicate that the low percentage of unreduced pollen grains formed in the Oryzopsis species have not been successful in producing polyploid plants till now, although we may encounter polyploid populations in our feature explorations.

Different cytological mechanisms are responsible for the production of $2 n$ gametes (Bertagnolle and Thomson 1995). Anaphase failure, cytomixis and multipolar cell formation have been reported as the main cytological mechanisms of unreduced gamete formation in some grass species including Bromus, Festuca and Stipa (Sheidai and Nouroozi 2005, Sheidai and BagheriShabestari 2007b, Sheidai et al. 2006). The occurrence of large number of univalents and the failure of chromosome movement to the poles as well as multipolar cell formation may be considered as the possible mechanisms of unreduced meiocyte formation in the Oryzopsis species as suggested before (Yazdanbakhsh et al. 2010). Therefore it seems that different cytological mechanisms, including changes in the chromosome number, significant changes in the number of genes controlling chromosome pairing, the occurrence of Bs and unreduced pollen grain formation along with hybridization, may have played a role in the evolution and diversification of the Oryzopsis species.

\section{Acknowledgements}

The present project has been partly supported by Shahid Beheshti University Grant. 


\section{References}

Bertagnolle, F. and Thompson J. D. 1995. Gametes with the somatic chromosome number: Mechanisms of their formation and role in the evolution of autopolyploid plants. New Phytol. 129: 1-22.

Bor, N. L. 1970.- In: Reschinger, K. H. (ed.), Flora Iranica 70, Akademische Druck. Verlagsanstalt, Graz, Austria, pp. 401-407.

Camacho, J. P. M., Sharbel, T. F. and Beukeboom, L. W. 2000. B-chromosome evolution. Philos. Trans. R. Soc. Lond., B, Biol. Sci. 355: 163-178.

Hitchcock, C. L. and Spellenberg, R. W. 1968. A new Oryzopsis from Idaho.- Brittonia 20: 162-165.

Johnson, B. L. and Rogler, G. A. 1943. A cyto-taxonomic study of an intergeneric hybrid between Oryzopsis hymenoides and Stipa viridula. Am. J. Bot. 30: 49-56.

- 1945a. Cyto-taxonomic studies in Oryzopsis. Bot. Gaz. 107: 1-32.

— 1945b. Natural hybrids between Oryzopsis hymenoides and several species of Stipa. Am. J. Bot. 32: 599-608.

- 1960. Natural hybrids between Oryzopsis and Stipa: I. Oryzopsis hymenoides $\times$ Stipa speciosa. Am. J. Bot. 47: 736-742.

- 1962. Natural hybrids between Oryzopsis and Stipa: II. Oryzopsis hymenoides $\times$ Stipa nevadensis. Am. J. Bot. 49: $540-546$.

- 1963. Natural hybrids between Oryzopsis and Stipa: III. Oryzopsis hymenoides $\times$ Stipa pinetorum. Am. J. Bot. 50: 228-234.

Love, A. and Love, D. 1981a. In Chromosome number reports LXXI. Taxon 30: 509-511.

Nasirzadeh, A., Hatami, A., Sadeqiyan, S. and Mirzai-Nadoushan, H. 2004. Cytomorphological studies on Oryzopsis species in Fars province. Project Report, No. 26629. Research Institute of Forest and Rangeland, Karaj.

Quicke, D. L. J. 1993. Principles and Techniques of Cotemporary Taxonomy. Blackie Academic \& Professional, Glasgow. pp. 50-100.

Rees, H. A. and Jones, R. N. 1977. Chromosome Genetics. Edward Arnold, London. pp. 60-160.

Sharma, M. L. and Sharma, K. 1979. Cytological studies in the North Indian grasses. Cytologia 44: 861-872.

Sheidai, M. and Inamdar, A. C. 1997. Cytomorphology of Asparagus taxa using multivariate statistical analysis. Nucleus 40: 7-12.

-, Mosalanejad, M. and Khatamsaz, M. 1999a. Karyological studies in Hyoscyamus species of Iran. Nordi. J. Bot. 19: 369-373.

—, Saeed, A. M. and Zehzad, B. 1999b. Meiotic studies of some Aegilops (Poaceae) species and populations in Iran. Edinb. J. Bot. 56: 405-419.

-, Arman, M., Mohamadi-Saeed, A. and Zehzad, B. 2000a. Notes on cytology and seed protein characteristics of Aegilops species in Iran. Nucleus 43: 118-128.

-, Nasirzadeh, A. and Kheradnam, M. 2000b. Karyotypic study of Echinops (Asteraceae) in Fars Province of Iran. Bot. J. Linn. Soc. 134: 453-463.

-, Arman, M. and Zehzad, B. 2002. Chromosome pairing and B-chromosomes in some Aegilops species and populations of Iran. Caryologia 55: 261-271.

— and Attaei S. 2005. Meiotic studies of some Stipa (Poacea) species and populations in Iran. Cytologia 70: $23-31$.

— and Fadaei, F. 2005. Cytogenetic studies in some Bromus L. species sec. Genea. J. Genet. 84: 189-194.

- and Nouroozi, M. 2005. Cytological studies on some species of Bromus sect. Bromus. Botanica Lithuanica. 11: $141-150$.

—, Attaei, S. and Khosravi-Reineh, M. 2006. Cytology of some Iranian Stipa (Poaceae) species and populations. Acta. Bot. Croat. 65: 1-11.

-, Noormohammadi, Z. and Sotodeh, M. 2006. Cytogenetic variability in several canola (Brassica napus) cultivars. Caryologia 59: 267-276.

— and Bagheri-Shabestarei, E-S. 2007a. Cytotaxonomy of some Festuca species and populations in Iran. Acta Bot. Croat. 66: $143-151$.

— and - 2007b. Cytomixis and unreduced pollen formation in some Festuca L. species of Iran. Caryologia 60: 364-371.

— and Rashid, S. 2007. Cytogenetic study of some Hordeum L. species in Iran. Acta Biol. Zseged. 51: 107-112.

-, Saeidi, S., Nourozi, M and Fadaei, F. 2008. Karyotype analysis in fourteen species and varieties of the genus Bromus L. (Poaceae). Cytologia 73: 453-461.

Sheidai et al. 2010

Spellenberg, R. W. and Mehlenbacher, L. E. 1971. Anatomical and cytological studies of an intergeneric hybrid, Oryzopsis hendersonii $\times$ Stipa lemmonii (Gramineae). Can. J. Bot. 49: 1565-1574.

Shechter, Y. 1969. Electrophoretic investigation of the hybrid origin of Oryzopsis contracta. pp. 19-25. In: L. Chandra (ed.). Advancing Frontiers of Plant Sciences, vol. 23. Impex India, New Delhi. p. 201.

Stebbins, G. L. 1981. Chromosomes and evolution in the genus Bromus (Gramineae). Bot. Jahrb. Syst. 102: 359-379.

— 1998. Evolution of seed hulls and chromosomes of Stipoid grasses. Grasslands 8: 1-5. 
Villeux, R. 1985. Diploid and polyploid gametes in Crop Plants: Mechanisms of formation and utilization in plant breeding. In: J. Janick (ed.). Plant Breeding Review, Vol. 3. AVI Publishing Co. Wesport, Connecticut. pp. 442.

Watson, L. and Dallwitz, M. J. 1992. Onwards. The grass genera of the world: descriptions, illustrations, identification, and information retrieval; including synonyms, morphology, anatomy, physiology, phytochemistry, cytology, classification, pathogens, world and local distribution, and references. Version 28th, November 2005.

Zahra Yazdanbakhsh, Masoud Sheidai, Ramezan-Ali Khavarinejad, Maryam Keshavarzi, Taher Nejadsattarei. 2010. Contribution to cytotaxonomy of Oryzopsis (Poaceae). Nord. J. Bot. 28 (In press). 